\title{
Antifungal Nano-Therapy in Veterinary Medicine: Current Status and Future Prospects
}

\author{
Mousa A. Alghuthaymi ${ }^{1}$, Atef A. Hassan ${ }^{2}$, Anu Kalia ${ }^{3, *(1)}$, Rasha M. H. Sayed El Ahl ${ }^{2}$, Ahmed A. M. El Hamaky ${ }^{2}$, \\ Patrik Oleksak ${ }^{4}$, Kamil Kuca ${ }^{4, *(D)}$ and Kamel A. Abd-Elsalam ${ }^{\text {,* }}$ (D) \\ 1 Biology Department, Science and Humanities College, Shaqra University, Alquwayiyah 19245, Saudi Arabia; \\ malghuthaymi@su.edu.sa \\ 2 Department of Mycology, Animal Health Research Institute (AHRI), Agriculture Research Center (ARC), \\ 12611 Giza, Egypt; atefhassan2000@yahoo.com (A.A.H.); rasha_hamza2005@hotmail.com (R.M.H.S.E.A.); \\ ahmed_elhamaky@yahoo.com (A.A.M.E.H.) \\ 3 Electron Microscopy and Nanoscience Laboratory, Department of Soil Science, College of Agriculture, \\ Punjab Agricultural University, Ludhiana 141004, India \\ 4 Department of Chemistry, Faculty of Science, University of Hradec Kralove, \\ 50003 Hradec Kralove, Czech Republic; patrik.oleksak@uhk.cz \\ 5 Plant Pathology Research Institute, Agricultural Research Center (ARC), 9-Gamaa St., 12619 Giza, Egypt \\ * Correspondence: kaliaanu@pau.edu (A.K.); kamil.kuca@uhk.cz (K.K.) \\ kamel.abdelsalam@arc.sci.eg (K.A.A.-E.); Tel.: +91-161-2401960 (A.K.)
}

check for updates

Citation: Alghuthaymi, M.A.; Hassan, A.A.; Kalia, A.; Sayed El Ahl, R.M.H.; El Hamaky, A.A.M.; Oleksak, P.; Kuca, K.; Abd-Elsalam, K.A. Antifungal Nano-Therapy in Veterinary Medicine: Current Status and Future Prospects. J. Fungi 2021, 7, 494. https://doi.org/10.3390/ jof7070494

Academic Editor: David S. Perlin

Received: 18 May 2021

Accepted: 16 June 2021

Published: 22 June 2021

Publisher's Note: MDPI stays neutra with regard to jurisdictional claims in published maps and institutional affiliations.

Copyright: (C) 2021 by the authors Licensee MDPI, Basel, Switzerland. This article is an open access article distributed under the terms and conditions of the Creative Commons Attribution (CC BY) license (https:// creativecommons.org/licenses/by/ $4.0 /)$

\begin{abstract}
The global recognition for the potential of nanoproducts and processes in human biomedicine has given impetus for the development of novel strategies for rapid, reliable, and proficient diagnosis, prevention, and control of animal diseases. Nanomaterials exhibit significant antifungal and antimycotoxin activities against mycosis and mycotoxicosis disorders in animals, as evidenced through reports published over the recent decade and more. These nanoantifungals can be potentially utilized for the development of a variety of products of pharmaceutical and biomedical significance including the nano-scale vaccines, adjuvants, anticancer and gene therapy systems, farm disinfectants, animal husbandry, and nutritional products. This review will provide details on the therapeutic and preventative aspects of nanoantifungals against diverse fungal and mycotoxin-related diseases in animals. The predominant mechanisms of action of these nanoantifungals and their potential as antifungal and cytotoxicity-causing agents will also be illustrated. Also, the other theragnostic applications of nanoantifungals in veterinary medicine will be identified.
\end{abstract}

Keywords: nanoantifungal; mycotoxin degradation; theragnostic; veterinary

\section{Introduction}

Fungal diseases are manifested as active infections and/or secretion of mycotoxins on growth of fungi in different tissues of animals. The specific fungal disorders include bovine mastitis, fungal diarrhea in calve, respiratory disorders, superficial, subcutaneous, and systemic infections and mycotoxicosis [1,2]. The variability of the extent of serious public health risk effects of fungal infections in livestock and other domesticated animals spans carcinogenic, nephrotoxic, and hepatotoxic effects following their consumption in the contaminated grains/animal food products [1,3]. Animal production holds considerable economic importance for humans, particularly in low-income countries [4]. Hence, published literature searches included different studies which evaluated the extent of incidences of fungal diseases claiming morbidity and mortality in animals of economic importance besides diverse techniques that can be followed to control the growth of fungal pathogens and secretion of mycotoxins $[1,5]$. The global prevalence of mycosis and mycotoxicosis related diseases in livestock is about $25 \%$. The traditional treatment procedures including the use of amphotericin $(\mathrm{AmB})$ have been evaluated to be relatively ineffective in most cases due to reactivation of latent fungal infections post medication treatment $[2,6]$. 
Likewise, the treatment of fungal infections with azoles (such as fluconazole, voriconazole and itraconazole) may lead to the emergence of resistant fungal pathogens due to excessive and frequent use $[7,8]$. To solve these issues of fungal disorders in animals, the search for novel effective nanotechnology-enabled antifungals has gained impetus. Further, dual benefits can be reaped through use of nanomaterials for both therapy and diagnosis of disease pathogens separately and for developing conjugate systems for simultaneous diagnosis and targeted release of the therapeutic agent, theragnostic systems [9]. Moreover, novel nano-based disease diagnosis and therapeutic systems have been developed for effective treatment of different animal diseases caused by fungal, parasitic and viral pathogens $[3,5]$. The antifungal nanomaterials can be applied for the diagnosis of the problems related to reproductive system of the animals [10] and for the protection of the physiological activities of animal genital organs and secretions [11,12]. Also, nanomaterials can be utilized to generate effective vaccines [13]. Nanomaterials can exhibit improved killing or inhibitory activity on fungal pathogens at lower doses and can also be utilized as drug delivery vehicles to help in targeted delivery of drugs [10]. Besides, novel formulations of antifungals or new devices that increase the likelihood of the medication being administered to the site of infection tend to be important in order to boost drug efficacy $[14,15]$. Therefore, the aim of the present review was to investigate the types of nanoantifungals and their applications in animal health. Also, their uses for mycotoxin degradation in animal feeds, and their therapeutic and preventive aspects were illustrated. Moreover, the mechanisms of nanoantifungal actions, toxicity, and ways to overcome the suspected toxicity will also be discussed.

\section{Nanoantifungals: Diversity and Relevance for Applications in Veterinary Medicine}

Metal/metal oxides and their nanocomposites such as zinc, silver, selenium, copperchitosan nanocomposite and other nanomaterials exhibit prominent fungicidal activity compared to their bulk counterparts $[9,16]$. These antifungal nanomaterials can be categorized into various forms according to their chemical sources and morphology [17,18]. A variety of nano-antifungals have been developed to cure different fungal diseases in animals and human beings (Figure 1).
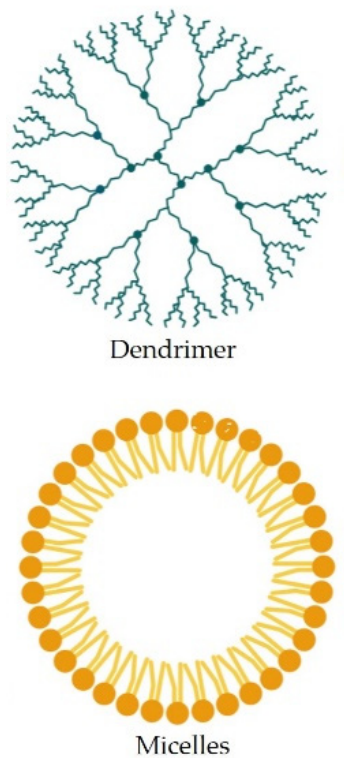
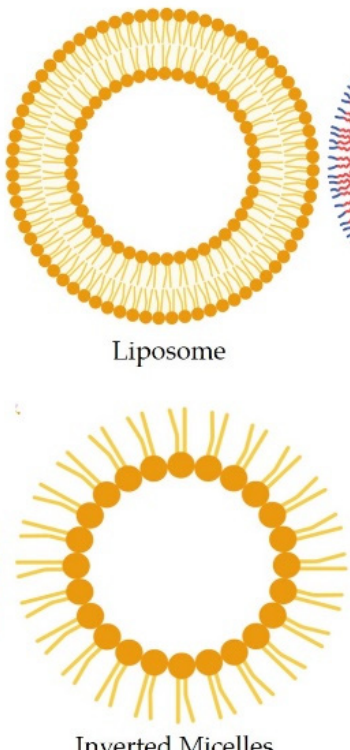
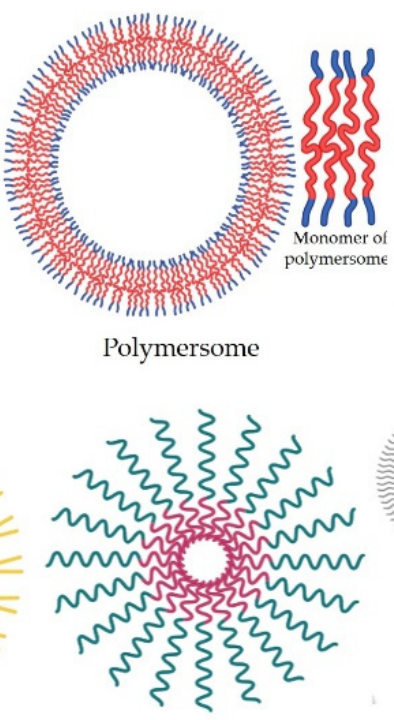

Polymeric Micelles



Solid Lipid nanoparticle (SLNs)

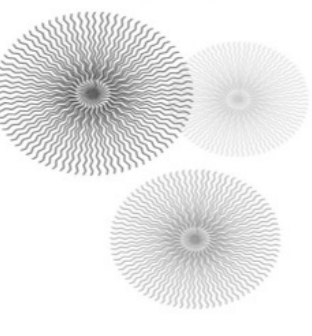

Spherulites



Polymeric nanoparticle

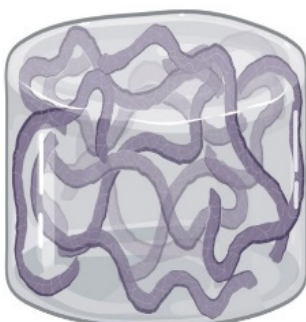

Polymer nano-gel

Figure 1. Nanovehicles for effective and smart delivery of therapeutic drugs and other anti-fungal agents. 


\subsection{Categories of Nanoantifungals in Veterinary Medicine on Basis of Their Chemical Origin, and Structure}

\subsubsection{Organic Synthetic and Natural Polymeric NPs}

A diversity of nanoparticles and nanoscale products can be developed from synthetic and natural polymers. These NPs are formed from natural and synthetic materials including saccharides and their derivatives such as chitosan, lipids and other biomolecules. A huge variability in the size of these nanomaterials has been reported, with size dimensions spanning from 0.5 to $100 \mathrm{~nm}$. These nanomaterials have high loading/conjugating capacities and have also been used for the development of hydrogel nanoformulations, particularly for the sugars and their derivatives [17]. Synthetic polymeric NPs can be composed of amphiphilic polymers such as caprolactone or PLGA which form a hydrophobic core that facilitates the transportation of hydrophobic drugs encrusted with a water-soluble coat [19]. These NPs have been used for transportation and delivery of drugs with low water-solubility such as amphotericin [20].

Solid lipid nanoparticles developed from a variety of lipids are upcoming drug delivery vehicles which exhibit great potential for lipophilic anti-cancer drugs. These can be easily combined with other materials to induce improved humoral antibody dependent immunity in the animals [21], besides their role in gene therapy by development of nucleic acid-based conjugates [22,23]. The oral, skin and parental routes of solid lipid NPs application are more effective in drug delivery and are highly absorbed [23].

Another category of polymeric nanoparticles includes the most popular forms called liposomes. These are non-toxic PEGylated NPs which are comprised of a two lipid (bilayer) cover shell having high solubility for fatty (hydrophobic) drugs. The first layer of the liposome is coated with a PEG layer to prevent any immune response towards the particles $[17,24]$. However, due to their vulnerability to get digested in the alimentary canal leading to loss of function, these nanoformulations are preferentially administered through parental and topical routes. Conjugating liposomes with biologically active antibodies can be useful for cancer cell treatment [23]. Further, liposomal formulations of dead pathogens can be utilized to develop vaccines [25]. The liposomes can also be conjugated with DNA to develop DNA vaccines [17]. Furthermore, the liposomes enable drug delivery and diffusion to targeted cell sites within the organism (Figure 1). Despite these benefits and potentially useful activities, these formulations are prone to changes during storage and also the encapsulated compounds may exhibit rapid destruction of their content on account of oxidation processes [26].

Similar to liposomes are the polymeric micelles with one basic difference from the former type that the latter are formed from exfoliated lipid bilayers and thus exhibit great potential to encapsulate lipophilic drugs. Therefore, micelles are hydrophobic core surrounded by a hydrophilic coat which increases their solubility in water [23].

Nano-cochleates are a specialized category of sub-micron to nanoscale solid particulate lipid-based drug carriers [27] which can be derived by the fusion of liposomes with metal cations and involve spiral rolling of continuous lipid bilayer [28,29]. These carriers can be efficiently loaded with both hydrophobic as well as hydrophilic drugs ensuring higher protection from gastrointestinal degradation of anti-fungal drugs particularly Amphotericin and thus enabling oral administration [30,31].

Synthetic polymeric nanoparticles primarily including dendrimers are derivatives of long-chain branched polymers such as polyamidoamines. Similar to micelle nanoparticles, dendrimers are water-soluble, exhibit high biological activities and possess comparatively a much smaller size than the other polymeric NPs discussed so far [26,32]. These attributes of the dendrimers do not allow stimulation of the immune response after parental administration. Dendrimers can be combined with drugs to improve their efficiency for treatment of a variety of animal disorders [26]. The dendrimer formulations have been successfully used for effective cancer treatments and may showcase multiplexed functions including detection of the tumor cells, entry through the cell membrane, targeted release of the conjugated anticancer drugs in the cytoplasm and finally the destruction and death of 
cancerous cells [23]. Dendrimers can also conjugate with the lipids of the cell membranes and this can create wide pores in the membrane that potentiate improved entrance of the drug containing dendrimer nanoparticles for targeted delivery leading to higher cell death rates [26].

\subsubsection{Nanoemulsions}

These are aqueous mixtures of oil or other hydrophobic components prepared by addition of oil to water overlaid by non-chemical surfactants $[1,16,33,34]$. The micelle size in the prepared nanoemulsions may vary from 0.5 to $>500 \mathrm{~nm}$. Nanoemulsions exhibit significantly high antifungal, bactericidal and virucidal activities. It may be attributed to greater adherence of the oil droplets on the surface of the microbial cells which facilitates the entrance of drugs to the cell $[5,17,35]$.

\subsubsection{Inorganic Metal/Non-Metal Nanomaterials}

These NPs are the first-choice nanomaterials to be used as nanoantifungals due to their low cost, easy application, eco-friendly characteristics and wide viability $[1,5]$. They exhibit potential as antifungals [29,36,37], besides the other biomedical benefits [24]. These nanomaterials may have individual particle size dimensions ranging from 1 to $100 \mathrm{~nm}$ with aggregate sizes have a higher size range.

Magnetic Iron Oxide Nanoparticles

Magnetic FeO NPs mainly consist of iron core $\left(\mathrm{Fe}_{3} \mathrm{O}_{4}\right.$ or $\left.\mathrm{Fe}_{2} \mathrm{O}_{3}\right)$ particles which have been used in several studies as significant antifungals against mycotoxigenic molds [34]. Drug delivery, heat therapy and imaging are other beneficial uses of iron core particles $[23,38,39]$. Moreover, the iron core can be conjugated with fluorescent shells and drugs or antibodies against targeted cancer cells [24]. Further, surface functionalization of these NPs by polyethylene glycol (PEG) can potentially help to prevent elicitation of the immune response.

\section{Semiconductor Quantum Dots}

Zinc selenide/telluride/sulphide quantum dots exhibit substantial antifungal potential [39]. QDs are core-shell aqueous materials which exhibit conjugation with drugs or other biological materials including nucleic acids (DNA/RNA), proteins and other biomolecules [17]. The biomolecule conjugated QDs have specific use for detection and diagnosis of diseases or their causative pathogens [23]. Further, QDs find peculiar applications for improved imaging and genetic analysis by observing cell activities under disease conditions, and targeted drug delivery [40].

\section{Silicate Nanomaterials}

These nanomaterials are comparatively biosafe, and do not exhibit high reactivities. Further, the silicate nanomaterials possess diverse morphologies spanning over different particle shapes and sizes which can be easily modified [23]. These silicate nanomaterials are also amenable to functionalization, and other coating treatments. Nanoshells are a specific class of silica nanomaterials which involve a thin metallic coating of the glass core [41]. These nanoparticles have been utilized for the diagnosis of the tumorous tissues [23,42] and simultaneous therapeutics applications [42-45].

\subsubsection{Carbon Nanomaterials}

Carbon nanomaterials have significant antifungal and antimycotoxin potential [3,5]. The carbon atom contents enable the destruction of pathogen cell walls [40]. These nanomaterials are insoluble in water and do not get digested in the alimentary tract or get excreted on oral administration [26]. The SE nanomaterials pass through the cell membranes of targeted cells to reach to the cytoplasm of the pathogens or cancer cells causing multiplexed 
damage resulting in the cell death [46]. Besides, buckyballs can ameliorate $\mathrm{pH}$ levels which help in drug delivery to targeted tissues [47]; gene therapy and DNA delivery [48].

\subsubsection{Nanobubbles}

These are gas core particles suspended in aqueous medium having general size dimensions ranging from $70-120 \mathrm{~nm}$ and function as carriers of gas molecules [49]. The nanobubbles are different from the other types of nanoparticles or nanoemulsions as these contain a shell comprised of polymer, phospholipids, proteins or anti-cancer therapeutic agent encasing a gas (generally oxygen) [50-52]. These nanomaterials are finding useful applications in diagnosis and targeted delivery of anticancer drugs [49,53].

\subsubsection{Nanovaccines and Nanoadjuvants}

Today, there are progressive advances in the application of nanotechnology for the production of vaccines. Nanovaccine formulations effectively activate the humoral immunity by a slow elaboration of antigens and thereby elevating the usefulness of vaccination $[17,54]$. These can be targeted to lymph tissues which significantly enhances the vaccine activities [55]. Nanomaterials conjugated with antibodies and other biological molecules can be used for the quick detection of pathogens and for effective treatment of the diseases caused by them [39]. However, the nanomaterials possess excellent adjuvant properties as these can bind to a variety of antigens/proteins of pathogenic origin to obtain nano-vaccines thereby replacing the use of the adjuvant material [55]. Different forms of nanomaterials used in animal antifungal nanotherapy was shown in Figure 2.



Figure 2. Various types of nano-based materials employed in antifungal nanotherapy in veterinary medicine.

\section{Applications of Nanoantifungals in Veterinary Medicine}

\subsection{Therapeutic and Preventive Aspects of Nanomaterials}

3.1.1. Metal/Metal Oxide/Non-Metal Oxide NPs and their Hybrids as Nanoantifungal Agents

The use of nanomaterials as antifungal agents is an established attribute. The nanomaterials that exhibit antifungal potentials have been evaluated in several studies with 
primary inhibitory impact on the vegetative growth of the fungal mycelia. The noble metal nanoparticles including the silver and gold nanoparticles possess potent antifungal properties. Nasar et al. [56] have evaluated the broad antimicrobial activity of AgNPs against human pathogenic bacteria (Escherichia coli, Klebsiella pneumonia, and Bacillus subtilis), and common fungal pathogen Aspergillus niger. The AgNPs have been found to be effective antifungals against dermal infections [57] Moreover, AgNPs can remove the human oral microbial infections caused by S. aureus and C. albicans [58], and C. albicans, and Trichophyton mentagrophytes infections in buffaloes [59]. The nanosized silver can inhibit the growth of Fusaium sp. at very low concentrations $(<100 \mathrm{ppm})[16,60]$ and led to decreased mycotoxin production [1,61]. Also, Kischkel et al. [37] observed the antifungal activity of the AgNPs against C. albicans, F. oxysporum and M. canis.

Abd-Elsalam et al. [62] have discussed the fungal growth inhibitory potential of a variety of metal oxide NPs. Among the metal oxide NPs, the most promising candidates are zinc oxide NPs which inhibited the Candida albicans growth at very low concentrations of 1.013-296.0 $\mu \mathrm{g} / \mathrm{mL}$ [63]. The shape and size of ZnO NPs has been an important characteristic that decides for the extent of the antifungal activity. Flower-shaped $\mathrm{ZnO}$ nanostructures inhibited the development of Aspergillus flavus and aflatoxin production at concentrations below $5 \mathrm{mM}$ [64]. The next metal oxide NPs showing considerable antimicrobial potential are the iron oxide NPs. A study on magnetic NPs $\left(\mathrm{Fe}_{2} \mathrm{O}_{3} \mathrm{NPs}\right)$ described the antifungal activity against $A$. flavus and prevention of the aflatoxin production [38]. While, Mouhamed et al. [65] documented the inhibitory effect of iron oxide NPs on ochratoxigenic Aspergillus sp. Moreover, Abd El-Tawab et al. [66] have detected the growth inhibitory properties of $\mathrm{Fe}_{2} \mathrm{O}_{3}$ NPs against causative pathogens of bovine skin diseases (Trichophyton verrucosum, T. mentagrophytes, and Dermatophilus sp.).

The coating or surface functionalization of the metal/metal oxide nanoparticles can further improve their antimicrobial properties. The chitosan NPs derived from deacetylated derivative of chitin can prevent growth of Fusarium sp., Rhizopus sp. and Aspergillus niger and thus can be used as an alternative to chemical pesticides [67]. Further, chitosan NPs have also been observed to inhibit fish pathogens under in vitro conditions [68]. Chitosan polymers can also be utilized to develop surface coatings on metal oxide NPs to improve their interactions and passage through the biological membranes. Recently, Abd-Elsalam et al. [69] have detected significant antifungal activity of CuNPs singly and in combination with chitosan against mycotoxigenic fungi, which also led to the prevention of aflatoxin production. The use of an acrylic resin reinforced with ZnONPs and Ag NPs can inhibit the growth of Candida albicans [70].

Nowadays, combinations of nanomaterials with beneficial biological active compounds are used to produce nanocomposites of significant use for animal health [1]. The conjugation and overlay of nanomaterials by other biological molecules are related to their chemical properties and used in detection of pathogens inside the body [71]. In this respect, Hassan et al. [1,5] have reported that the conjugation of metals nanomaterials with natural oils significantly improved the antifungal activity. They have detected that the composites of AgNPs, ZnONPs, and essential oils can effectively prevent the growth of fungal and bacterial pathogens. Hybrids of Ag NPs/essential oil were employed in therapy of bovine skin and udder infections [5,72] and carbon NPs [73]. Hassan et al. [5,16,74] have reported the efficient conjugation of ZnNPs and AgNPs with cinnamon and olive oils for use at low safe doses for inhibition of growth of toxigenic A. flavus and E. coli and production of respective toxins, whereas, Wang et al. [75] successfully detected that the hybrid of Au NPs with antibodies help in immune-chromatographic exploration and diagnosis of toxic $\mathrm{AFM}_{1}$ in milk. Similar activities were obtained for QDs to observe events and activities of body cells that were found to be better than the use of traditional dyes and this helped for release of drug to the required site of infection $[9,76]$.

Nanoparticles can also be conjugated with known standard antifungal agents or other molecules where these NPs function as nanovehicles for better delivery of the antifungal therapeutic agents at the targeted site. Therefore, common antifungal agents can also 
be conjugated on the metal or metal oxide NPs to enhance their antifungal activities. Kischkel et al. [29] have illustrated the potentials of different types of nanoantifungals for the treatment of mycosis caused by Candida sp. and Aspergillus sp. Hamad et al. [77] have developed a gold nanorod-fluconazole nanoconjugate which exhibited significantly high antifungal activity ( 9 to 12 -fold) against $C$. albicans compared to either component alone, whereas, Huang et al. [36] reported the possibility of using AgNPs as antifungals singly or in conjugation with epoxiconazole (8:2 and 9:1), respectively. The concentration of AgNPs required to suppress the growth of $50 \%$ of the fungal colony was $170.20 \mu \mathrm{g} / \mathrm{mL}$. The combination of AgNPs with fluconazole and florfenicol produced more antimicrobial potential against the causes of animal diseases than their single forms [5].

Inorganic mesoporous silica nanoparticles (MSNs) can also act as nanocarriers for drug delivery to target affected cells inside the body [78]. Functionalized silica NPs can be tethered to drug molecules or they can also adsorb or sequester the drug compound on the surface or inside the nanopores thereby elevating their delivery to the target organs [79,80]. Kanugala et al. [81] have developed phenazine-1-carboxamide-functionalized MSN-based antimicrobial biomaterial surfaces to prevent the formation of bioflms on medical implants. The developed MSNs exhibited superior anti-Candidal activity besides polymicrobial antibiofilm potential. Silica NPs can also be used for the development of topical cream formulations to treat skin fungal infections. Montazeri et al. [82] have synthesized and evaluated an aminopropyl functionalized MSN-econazole topical cream formulation against Candida albicans skin infections and observed improved antifungal activity at lower concentrations of the loaded drug.

\subsubsection{Polymer Nanoparticles for Antifungal Drug Delivery}

Recent drug and vaccine delivery strategies in biomedical research advocate the use of nanomaterials for successful delivery of drugs to targeted cells and tissues [10]. These strategies are beneficial as they can ensure the delivery of drugs to target tissues resulting in a decrease in the amount and required doses for the treatment of diseases. The most promising nanodelivery agents for drugs can be the polymer nanoparticles encapsulating antifungal drugs. In these respects, chitosan (CS) NPs which themselves possess considerable antifungal potential can be used for the delivery of the antibiotic drugs [68]. The encapsulation of antifungal drugs or development of their formulation as nanoemulsions can improve their action potential. Deaguero et al. [83] observed that nanoencapsulation of miconazole in cholesterol/sodium oleate vesicles have significant antifungal activity against several fungal pathogens. Siopi et al. [84] have reported that the liposome-encapsulated amphotericin B possess significant therapeutic potential against mycotic respiratory infections in animals caused by A. fumigatus.

Drug molecules can also be nanoformulated as nanomicelles comprised of a hydrophobic core and hydrophilic shell which improves the water solubility and therefore bioavailability of the hydrophobic drugs [85]. Further, these nanosystems can be used for the targeted delivery of the drug [86], treatment of cancer in animals [87] and to ensure drug delivery without stimulation of immunity [88].

\subsubsection{Carbon Nanomaterials as Nano-Antifungals}

Different forms of carbon-based nanomaterials also exhibit antimicrobial activity against bacterial and fungal pathogens causing diarrhoea [3]. These nanomaterials can inhibit the growth of E. coli and mycotoxigenic fungi [89]. Furthermore, conjugation of sugars with CNTs improve the ability to affect the viability of C. albicans, A. flavus [5]. Several benefits of nanoantifungal applications were detected, as illustrated in Figure 3. 




Figure 3. Theragnostic applications of nanoantifungals in animal science.

\subsubsection{Nanocomposites for Antifungal Drug Delivery Agents}

The nanocomposites of natural materials such as carbohydrates and proteins with polymers have the ability of effectively releasing of these materials at targeted sites [40]. However, the modified CS NPs are capable of drug delivery to diseased tissues at lower doses than traditional chemical cancer therapy. They can be used as an adjuvant for effective animal vaccination against infections. The parental administration of nanoshells comprised of silica core attached with metals NPs and drugs in animals can be useful to search and can be directed to target cancer cells [90].

The nanocomposites qualify quite uniquely considering the non-stimulation of the elaborate immune response aspect [91]. The embedding or encapsulation of the drug in polymer blend-based nanocomposite also improves its antifungal potential. Terbinafine hydrochloride was introduced into the polycaprolactone (PCL)/gelatin nanofibers generated by the hydrothermal method [92]. The resulting wound dressings were tested for their antifungal potential.The researchers were successful in inhibiting the T. mentagrophytes and Aspergillus fumigatus due to slow release of the embedded drug molecules from the nanocomposite fibers over time [92].

\subsection{Antifungal Nanomaterials for Management of Mycotoxins in Animal Feeds}

The morbidity and mortality caused due to global incidences of mycotoxicosis in animal and poultry industry have serious economic repercussions affecting the productivity $[1,3,5,93]$. Recently, it was reported that $\mathrm{ZnO} N P s$ and $\mathrm{Fe}_{2} \mathrm{O}_{3} \mathrm{NPs}$ have antifungal activity against ochratoxigenic Aspergillus and hence prevent mycotoxin synthesis [57,65]. The supplementation of Zn NPs in aflatoxicated feed of rats and rabbits resulted in the removal of the carcinogenicity of aflatoxins on the kidney and liver [72,94]. The ZnNPs and AgNPs can inhibit the growth of Fusarium poae and prevent formation of trichothecenes mycotoxin [16]. The Ag NPs can eliminate aflatoxins in chickens feed $[95,96]$. Biosynthesized spherical SeNPs produced by Saccharomyces cerevisiae and originated from selenous acid and sodium sulfite were able to inhibit pathogenic saprophytes, yeasts, and dermatophytes [97]. Fadl et al. [98] have reported that CuNPs inhibit ochratoxigenic molds and prevent ochratoxin production in a fish feed. 
Apart from the metal/metal oxide nanoparticles, carbon nanomaterials, particularly carbon nanodiamonds, can ameliorate the adverse effects of mycotoxins by the process of immobilization of the mycotoxins [99]. While, another report by Hassan et al. [3] detected the activity of CNTs in suppression the toxicity of A. flavus at a concentration of $125 \mu \mathrm{g} / \mathrm{mL}$. Therefore, the primary modus operandi for the anti-mycotoxigenic effects of both nanomaterials and nanocomposites such as iron NPs [100] and $\mathrm{MgO}^{-\mathrm{SiO}_{2}}$ nanocomposite [101] is through adsorption of the mycotoxins.

Nanohybrids such as polyene-functionalized magnetic NPs possess enhanced antifungal activity against opportunistic oral fungal pathogens such as Candida sp. [102]. A miconazole nanocarrier (MCZ) based on iron oxide nanoparticles (IONPs) functionalized with CS was prepared, characterized and screened for antifungal activity against Candida albicans and Candida glabrata biofilms. A nanocarrier with less than $50 \mathrm{~nm}$ dimeter presenting MIC values lower than those observed for high diameter and showed synergism against C. albicans [103]. Similarly, nanoformulations of known antifungal agents can improve the action spectrum of these agents and enhance the antibiofilm potential. The antimicrobial and antibiofilm effects of a colloidal nanocarrier for chlorhexidine (CHX) on yeast and bacteria such as Candida glabrata and Enterococcus faecalis were evaluated. The $\mathrm{CHX}$ nanocarrier has an excellent ability for the management of oral diseases linked to C. glabrata and E. faecalis [104].

The nanocomposites derived from metal oxide and carbon nanomaterials have also been evaluated for anti-mycotoxin properties. A magnetic carbon nanocomposite derived from bagasse was observed to degrade AFB1 [105], while graphene oxide nanocomposites caused a reduction in the occurrence of three prominent Fusarium toxins i.e., ZEA, FB, and deoxynivalenol [106] and modified halloysite nanotubes [96,107]. Also, detoxification of AFB1 by a magnetic graphene oxide nanocomposite has been reported by Ji and Xie [108]. González-Jartín et al. [109] observed that nanocomposites of carbon, bentonite, and aluminum oxide eliminated up to $87 \%$ of the mycotoxins with an adsorption efficiency of $450 \mu \mathrm{g} / \mathrm{g}$. Chitosan-stabilized selenium nanoparticles have a significant ability to improve the toxic effects of aflatoxicosis in rats $[35,110]$. Further, the SeNPs exhibited important inhibitory effects on A. parasiticus, A. ochraceus, and Aspergillus nidulans growth at concentrations varying from $0.1-0.5 \mathrm{mg} / \mathrm{L}$ and ameliorate the dysfunction and hepatic apoptosis induced by AFB1 [30]. Chitosan-coated $\mathrm{Fe}_{3} \mathrm{O}_{4}$ particles have been reported to be substantially useful for patulin decontamination with no toxic response or histopathology in treated mice $[106,111]$. Recently, Hassan et al. have also assessed the efficiency of the copper-CS nanocomposites for the removal of the aflatoxins and ochratoxins in poultry (personal communication).

Conjugating metal oxide nanoparticles with other antimicrobial components such as essential oils, curcumin or ozone can improve the antimycotoxigenic activities. Also, the antimicrobial, anti-aflatoxins, and anti-shigella toxins potentials of nanoemulsion of cinnamon oil and $\mathrm{ZnO}$ NPs towards to fungal causes of dysentery in buffaloes were detected [16]. Hassan et al. [72] observed that conjugating ZnO-NPs along with probiotic and curcumin improved the inhibitory activities on mycotoxin producing Fusarium sp. besides significantly decreasing their ability for mycotoxin production. The combined application of $\mathrm{ZnO}$ NPs, probiotic and curcumin $(\mathrm{ZnO}$ NPs $(100 \mu \mathrm{g} / \mathrm{mL})+$ probiotic $(0.5 \%)$ or curcumin $(0.5 \%))$ resulted in complete detoxification of Fusarium mycotoxins [72]. Hassan et al. [16] reported alteration in the gene expression profile of the $\mathrm{ZnO}$ and essential oil treated E. coli and A. flavus through RT-PCR studies that helped to elucidate the efficacy of the treatments. When the treatment doses of ZnO NPs, cinnamon oil, and olive oil increased, the AflR and Stx toxin genes expression efficacy, the molecular weight of DNA, and cycle threshold were decreased. The synergistic activity used lower doses of combined form than each alone. Hamza et al. [112] used hybrid $\beta$-glucan mannan lipid particles (GMLPs)-humic acid iron nanoparticles (HA-FeNPs) as an AFB1 binder provides a high binding capacity and a safe enhanced mycotoxin binding material. 


\subsection{Cancer Theragnostics}

Nanoantifungals and their hybrids have the potential to penetrate cancer cells and accumulate in the cytoplasm of cancer cells leading to damage, followed by an inhibitory action leading to death [111]. Similar properties of nanoparticles can help in early and reliable detection of various types of cancer tissues [112]. Hybrid nanocarrier and natural body sugars-derived NPs can help in carrying and release of drugs as in cases of lung cancer [88].

\subsubsection{Cancer Therapeutic Applications}

\section{Nanoantifungal Agents and Their Hybrids}

Zn NPs enable killing of the tumor cells that may also help to preserve the immune cells intact and this activity can be used for both tumor detection and therapy (cancer theranostics) simultaneously [113]. Anticancer drug-functionalized iron or zinc nanoparticles can improve the adherence of the drug-NP conjugate to the target tumor cell and can ensure targeted release of the anticancer drugs to malignant or tumor cells [114-116]. Another study detected that magnetic NPs encapsulated with silica can be effectively used as antitumor drugs [117]. Polymeric nanoparticles such as solid lipid nanoparticles and dendrimers are also potent smart nanovehicles ensuring the targeted delivery of drug molecules in cancer tissues. Nanoencapsulation of 5-fluorouracil in solid lipid nanoparticles improved the specific problems associated with rapid metabolism and shorter life time [118]. This nanovehicle therefore improved the use of the 5-fluorouracil for treatment of colorectal cancer conditions. Meena et al. [40] and Hassan et al. [3] detected the major benefits of CNTs fungal and tumor infections treatment. Xie et al. [119] successfully demonstrated the relevancy of a carbon nanoparticle suspension injection for the diagnosis of thyroid carcinoma.

\section{Nanocomposites}

The combination of nanomaterials and drugs, sugars, proteins and DNA potentiated detection and control of animal tumors [120]. The parental inoculation of nanocomposite of Au NPs and gum Arabic act as fluorescent agents in canine cancer therapy [121]. Osama et al. [76] found a significant ability of liposomes to reach the targeted tumors tissues and effective drugs release. Osama et al. [76] estimated the viability of liposome hybrid NPs in detection and therapy of canine tumors in the spleen. Furthermore, dendrimers, the hybrid nanomaterials have the potentials to be conjugated with biological materials and anticancer drugs and released them in targeted tissues in the body and hence excellent tumor detection and treatment were achieved (Figure 4). The combination of MSNPs/folic acid resulted in possibilities of direction of a drug to tumor cells and hence treatment of tumors in mice [122].

\subsubsection{Cancer Diagnosis Applications}

The essential role for the correct disease diagnosis involves clear observation of the affected tissues activities via imaging.

\section{Nanoantifungal-Based Diagnostic Approaches}

The majority of antifungal nanomaterials such as magnetic nanoparticles (MNPs) can be employed in MRI imaging of body tissues [123]. A particular benefits of these NPs is their greater ability to penetrate through the cell membranes and reach blood supply to contrasts of targeted cells as canine stem cells [124]. Superparamagnetic iron oxide nanoparticles functionalized with PEG and ${ }^{64} \mathrm{Cu}$ exhibited encouraging PET and MRI imaging properties besides possessing good stability [125]. Packed graphene oxide also possesses significant potential for quick and sensitive detection and treatment of infections [126]. QDs, the semiconductor materials exhibit huge potential for disease diagnostic applications [127-129]. 




Figure 4. Immuno-modulatory and other functions of nano-antifungals for cancer therapeutics.

Nanocomposites

QDs as Co@Cd-Se core-shell nanocomposites and FePt-Zn nanosponges have fluorescence properties that help in imaging biological events [130]. However, the conjugation of QDs with biological materials (AS enzymes, antibodies and DNA) caused markers imaged by a fluorescence signal [131,132]. In addition, QDs are more photostable than traditional chemical dyes which makes them to be appropriate for use in bioimaging $[133,134]$.

\subsection{Nanoantifungal-Enabled Improved Animal Nutrition, and Breeding}

Recent research focused on the use of nanomaterials for improving the efficiency of animal production has gained the attention of veterinary experts. Some relevant aspects include the reports on the supplementation of CuNPs, ZnNPs and SeNPs in chicken feed that elevated their productivity of egg and meat $[135,136]$. Addition of ZnO NPs to broiler chick feeds resulted in elevation of their health status and growth performance $[137,138]$. Moreover, multiplexed positive effects of these nanomaterials can be identified such as the fact these materials increased the growth rates, reproductive viability, and meat and egg quality of animals and poultry [4]. Also, the supplementation of coated nanomaterials kept their viability against the worst environmental conditions such as digestive enzymes, light and oxidation $[40,76]$. Another study on injection of Ag NPs alone or in combination with cysteine/threonine amino acids in chicken embryos increased the formation of breast tissue and also improved the chicken immunity through the immunomodulatory properties of the NPs [139]. Also, semiconductor QDs have been successfully utilized for the detection and imaging of physiological events related to functioning of the spermatozoa and female gametes [140] and imaging of fertilization events in male pig gonadal tissue [128]. QDs have the potential to determine the spermatozoon and oocyte movements, hence significant improvement in animal production occurred [12]. NPs can be used not just imaging for the elucidation of the gamete functions, but also as antibody or lectin conjugated metals for the segregation or fractionation of abnormal sperm from active healthy sperm if the functionalized antibodies can detect the defective sperms [141].

Antifungal nanomaterials showed significant activities for elevation of the efficacy of animal reproduction aspects $[9,12]$. Nanomaterials can be utilized to improve the life and efficacy of preserved semen specimens. The supplementation of polyethyleneimine or propyltriethoxysilane-functionalized mesoporous silica NPs did not exhibit any negative 
impact on any sperm activity-related properties [142]. Thus, these NPs may help in preservation of the semen quality during in vitro artificial insemination [142]. Another report showcased an improvement in the fertilization potential of the buffalo sperm on addition of titanium oxide NPs $\left(\mathrm{TiO}_{2} \mathrm{NPs}, 10 \mu \mathrm{g} / \mathrm{mL}\right)$ [143].

Administration of NPs of antioxidant compounds or vitamins can improve the ability of the organism to withstand and avoid oxidative stresses. Oral administration of $\alpha$ tocopherol NPs in equine animals showed significantly improved rates of absorption and $\alpha$-tocopherol plasma levels because of maintenance of the high oxidative status in race horses undergoing strenuous training [144]. The pig health status can be elevated by supplementation of micellar NPs conjugated with vitamin E to pigs [145]. Nanosized nutrients and vitamins used as a feed additive in feeds and pass through the alimentary tract of an animal to the blood vessels and distributed to different biological tissues cause their significant improvement [146].

\section{Nanoantifungals: Can These Be the Future Innovations in Veterinary Biomedicine?}

\subsection{Mechanism of Action of Nanomaterials as Antifungal Agents}

Nanomaterial possess a range of activities to inhibit the growth and multiplication of fungal-pathogens resulting in cell damage and loss of functions $[3,5,35,38]$. Nanomaterials exhibit a large surface area compared to the corresponding bulk materials [147]. These materials interact with the various biomolecules in the biological milieu eliciting formation of reactive oxygen species. The action of several nanoantifungals leads to an augmentation of intracellular ROS, an important mediator for exerting antifungal effects. The antifungal activity of nanosilver has been associated with the induction of mitochondrial dysfunctional apoptosis through an increase in oxidative stress via ROS generation especially hydroxyl radicals [148]. The ROS generation is initiated as a response to attachment of antifungal nanomaterial with targeted cells leading to elaboration of $\mathrm{O}_{2}$ atom and metal ions [149], whereas, the elaborated $\mathrm{O}_{2}$ increases the oxidative stress causing damage of the mitochondria proteins, leading to denaturation and loss of their functions. These potentials of ROS production have been observed on supplementation of $\mathrm{C}_{60}$ fullerenes, SWNTs, and QDs $[1,5,150]$.

\subsection{Cytoxicity Risks of the Use of Nanoantifungal Agents}

The continuous awareness about the toxicity risk of nanomaterials to animal and the environment have led to refusals of applications of nanomaterials in animal science by several international authorities [151]. The toxicity of nanomaterials can be affected by a variety of factors such as particle size, dose level, type of animal species and the period of exposure [94] and the physico-chemical characters of the nanomaterials used [152]. Chronic exposure of buffalo sperm to ZnNPs and TiONPs $(100 \mu \mathrm{g} / \mathrm{mL})$ caused several abnormalities resulting in suppression of viability and diminished fertility [143], while, sperm exposure to 100-500 $\mu \mathrm{g} / \mathrm{mL}$ of Zn NPs caused their damage and rapid death [153]. Hence, the estimation of safe doses of the used nanomaterial should be investigated in laboratory animals before application to field animals [35,72,94].

Furthermore, upon ingestion of nanomaterials by humans and animals they enter the alimentary tract, reach the circulatory system and are carried over via the liver and spleen $[35,154,155]$, whereas, inhalation and skin exposure to nanomaterials allows for their penetration through the skin tissues and nerve cells $[152,155]$. Inhalation of $\mathrm{TiO}_{2} \mathrm{NPs}$ was identified to have an effect in the development of lung cancer [154]. When NPs reach blood vessels, pathological effects occur such as blood clots and disorders in the cardiovascular system functions [156]. Inhalation of low doses of $\mathrm{TiO}_{2} \mathrm{NPs}$ can cause vascular disorders in rats [157], besides inhalation of single wall and multiwall CNTs [158,159]. We have little knowledge about toxicity and the journey of the nanoparticles in the animal body from the site of administration, passage through absorption, blood vessels, distribution in body tissues and their further journey. Hence, broad toxicological studies are needed 
before launching commercially viable nanotechnology applications in biomedicine and animal health.

\subsection{Safety Concerns of Nanoantifungals}

There are many challenges related to the potentially toxic effects of nanomaterials. Incorporation of nanomaterials into polymeric hydrogel matrices may reduce the toxicity and improve its efficacy because of sustained and controlled release of the incorporated NPs. The effective delivery of the nanomaterials can be ensured by their functionalization with polymers at low doses to avoid elicitation of the cellular toxicity $[1,3,5,160]$. Moreover, several benefits of nanomaterials use for improvement in biomedical applications have also been realized. Although, information related to their harmful impacts is not sufficient and special attention is required for identification of their toxicity risk before practical biomedical applications can be approved for use.

\section{Conclusions and Future Perspectives}

Over the past decades, nanotechnology has offered progressive novel advances to improve animal health and production. Today, several nanomaterials are used as nanoantifungals, besides having other benefits such as disease detection, diagnosis and therapy, use of additives to animal feed and their products, and finally food safety. The essential therapeutic and preventive activities of nanoantifungals, particularly the zinc and copper nanomaterials, have been evaluated against a variety of fungal diseases and mycotoxicosis in animals. Also, super paramagnetic iron, semiconductor quantum dots and gold nanoparticles are finding applications for early and sensitive detection followed by detailed prognosis and therapy of cancer. Both inorganic and organic polymeric nanomaterials have also been utilized for targeted delivery of various vaccines, quick and on-site detection of pathogens or their signature protein and other biological molecules. The mechanisms of nanoantifungal activity are related to their ability to penetrate the cell membrane, damage the cytoplasmic contents, leading to loss of function and death of the cells. Therefore, further studies illustrating the cellular toxicity mechanisms that result in oxidative stress and leading to genotoxicity and cancers need a detailed evaluation to manipulate the roles of nanomaterial in animal health. Moreover, the toxicity risks of nanomaterials must be determined before application of nanomaterials in veterinary medicine for safeguarding the health of the animals and their role in animal production.

Author Contributions: Conceptualization, A.A.H., M.A.A.; resources, A.A.H. writing-original draft preparation, A.A.M.E.H., A.K.; writing-review and editing, R.M.H.S.E.A., K.K., K.A.A.-E.; supervision, K.A.A.-E.; funding acquisition, K.K., P.O. All authors have read and agreed to the published version of the manuscript.

Funding: This work was supported by the project UHK VT2019-2021.

Institutional Review Board Statement: Not applicable.

Informed Consent Statement: Not applicable.

Data Availability Statement: Not applicable.

Acknowledgments: The authors wish to express their grateful appreciation and heartfelt thanks to M.K. Refai, Professor of Microbiology, Cairo University, Egypt for his continuous assistance and advice for initiating this work.

Conflicts of Interest: The authors declare no conflict of interest.

\section{References}

1. Hassan, A.A.; Sayed-ElAhl, R.M.H.; Oraby, N.H.; El-Hamaky, A.M.A. Metal nanoparticles for management of mycotoxigenic fungi and mycotoxicosis diseases of animals and poultry. In Nanomycotoxicology; Elsevier: Amsterdam, The Netherlands, 2020; pp. 251-269; ISBN 9780128179987.

2. Tiew, P.Y.; Mac Aogain, M.; Ali, N.A.B.M.; Thng, K.X.; Goh, K.; Lau, K.J.X.; Chotirmall, S.H. The Mycobiome in Health and Disease: Emerging Concepts, Methodologies and Challenges. Mycopathologia 2020, 185, 207-231. [CrossRef] 
3. Hassan, A.A.; Mansour, M.K.; Sayed-ElAhl, R.M.H.; El Hamaky, A.M.A.; Oraby, N.H. Toxic and beneficial effects of carbon nanomaterials on human and animal health. In Carbon Nanomaterials for Agri-Food and Environmental Applications; Elsevier: Amsterdam, The Netherlands, 2020; pp. 535-555; ISBN 9780128197868.

4. Fesseha, H.; Degu, T.; Getachew, Y. Nanotechnology and its Application in Animal Production: A Review. Vet. Med. Open J. 2020, 5, 43-50. [CrossRef]

5. Hassan, A.A.; Mansour, M.K.; El Hamaky, A.M.; Sayed-ElAhl, R.M.H.; Oraby, N.H. Nanomaterials and Nanocomposite Applications in Veterinary Medicine; Elsevier: Amsterdam, The Netherlands, 2020; ISBN 9780128213544.

6. Brunet, K.; Alanio, A.; Lortholary, O.; Rammaert, B. Reactivation of dormant/latent fungal infection. J. Infect. 2018, 77, 463-468. [CrossRef]

7. Di Mambro, T.; Guerriero, I.; Aurisicchio, L.; Magnani, M.; Marra, E. The yin and yang of current antifungal therapeutic strategies: How can we harness our natural defenses? Front. Pharmacol. 2019, 10, 1-11. [CrossRef] [PubMed]

8. Gintjee, T.J.; Donnelley, M.A.; Thompson, G.R. Aspiring Antifungals: Review of Current Antifungal Pipeline Developments. J. Fungi 2020, 6, 28. [CrossRef]

9. El-Sayed, A.; Kamel, M. Advanced applications of nanotechnology in veterinary medicine. Environ. Sci. Pollut. Res. 2020, 27, 19073-19086. [CrossRef]

10. Youssef, F.S.; El-Banna, H.A.; Elzorba, H.Y.; Galal, A.M. Application of some nanoparticles in the field of veterinary medicine. Int. J. Vet. Sci. Med. 2019, 7, 78-93. [CrossRef]

11. Saragusty, J.; Arav, A. Current progress in oocyte and embryo cryopreservation by slow freezing and vitrification. Reproduction 2011, 141, 1-19. [CrossRef]

12. Hill, E.K.; Li, J. Current and future prospects for nanotechnology in animal production. J. Anim. Sci. Biotechnol. 2017, 8, 1-13. [CrossRef]

13. Souza, A.C.O.; Amaral, A.C. Antifungal therapy for systemic mycosis and the nanobiotechnology era: Improving efficacy, biodistribution and toxicity. Front. Microbiol. 2017, 8, 1-13. [CrossRef]

14. Sousa, F.; Ferreira, D.; Reis, S.; Costa, P. Current insights on antifungal therapy: Novel nanotechnology approaches for drug delivery systems and new drugs from natural sources. Pharmaceuticals 2020, 13, 248. [CrossRef]

15. Martínez-Montelongo, J.H.; Medina-Ramírez, I.E.; Romo-Lozano, Y.; González-Gutiérrez, A.; Macías-Díaz, J.E. Development of nano-antifungal therapy for systemic and endemic mycoses. J. Fungi 2021, 7, 158. [CrossRef]

16. Hassan, A.A.; Abo-Zaid, K.F.; Oraby, N.H. Molecular and conventional detection of antimicrobial activity of zinc oxide nanoparticles and cinnamon oil against escherichia coli and aspergillus flavus. Adv. Anim. Vet. Sci. 2020, 8, 839-847. [CrossRef]

17. Torres-Sangiao, E.; Holban, A.M.; Gestal, M.C. Advanced nanobiomaterials: Vaccines, diagnosis and treatment of infectious diseases. Molecules 2016, 21, 867. [CrossRef]

18. Riley, M.K.; Vermerris, W. Recent advances in nanomaterials for gene delivery-A review. Nanomaterials 2017, 7, 94. [CrossRef]

19. Ferraz, M.P.; Mateus, A.Y.; Sousa, J.C.; Monteiro, F.J. Nanohydroxyapatite microspheres as delivery system for antibiotics: Release kinetics, antimicrobial activity, and interaction with osteoblasts. J. Biomed. Mater. Res. Part A 2007, 81A, 994-1004. [CrossRef]

20. Prabhu, R.H.; Patravale, V.B.; Joshi, M.D. Polymeric nanoparticles for targeted treatment in oncology: Current insights. Int. J. Nanomedicine 2015, 10, 1001-1018. [CrossRef]

21. Krishnan, S.R.; George, S.K. Nanotherapeutics in Cancer Prevention, Diagnosis and Treatment. Pharmacol. Ther. 2014. [CrossRef]

22. Mishra, B.; Patel, B.B.; Tiwari, S. Colloidal nanocarriers: A review on formulation technology, types and applications toward targeted drug delivery. Nanomed. Nanotechnol. Biol. Med. 2010, 6, 9-24. [CrossRef]

23. Mohanty, N.N.; Palai, T.K.; Prusty, B.R.; Mohapatra, J.K. An Overview of Nanomedicine in Veterinary Science. Vet. Res. Int. 2014, 2, 90-95.

24. Elgqvist, J. Nanoparticles as theranostic vehicles in experimental and clinical applications-focus on prostate and breast cancer. Int. J. Mol. Sci. 2017, 18, 1102. [CrossRef]

25. De Serrano, L.O.; Burkhart, D.J. Liposomal vaccine formulations as prophylactic agents: Design considerations for modern vaccines. J. Nanobiotechnology 2017, 15, 1-23. [CrossRef]

26. Jurj, A.; Braicu, C.; Pop, L.A.; Tomuleasa, C.; Gherman, C.D.; Berindan-Neagoe, I. The new era of nanotechnology, an alternative to change cancer treatment. Drug Des. Devel. Ther. 2017, 11, 2871-2890. [CrossRef]

27. Nagarsekar, K.; Ashtikar, M.; Thamm, J.; Steiniger, F.; Schacher, F.; Fahr, A.; May, S. Electron microscopy and theoretical modeling of cochleates. Langmuir 2014, 30, 13143-13151. [CrossRef]

28. Pawar, A.; Bothiraja, C.; Shaikh, K.; Mali, A. An insight into cochleates, a potential drug delivery system. RSC Adv. 2015, 5, 81188-81202. [CrossRef]

29. Kischkel, B.; Rossi, S.A.; Santos, S.R.; Nosanchuk, J.D.; Travassos, L.R.; Taborda, C.P. Therapies and Vaccines Based on Nanoparticles for the Treatment of Systemic Fungal Infections. Front. Cell. Infect. Microbiol. 2020, 10. [CrossRef]

30. Aigner, M.; Lass-Flörl, C. Encochleated amphotericin B: Is the oral availability of amphotericin B finally reached? J. Fungi 2020, 6, 66. [CrossRef]

31. Faustino, C.; Pinheiro, L. Lipid systems for the delivery of amphotericin B in antifungal therapy. Pharmaceutics 2020, 12, 29. [CrossRef]

32. Vikrama Chakravarthi, P.; Balaji, S.N. Applications of nanotechnology in veterinary medicine. Vet. World 2010, 3, 477-480. [CrossRef] 
33. Aboalnaja, K.O.; Yaghmoor, S.; Kumosani, T.A.; McClements, D.J. Utilization of nanoemulsions to enhance bioactivity of pharmaceuticals, supplements, and nutraceuticals: Nanoemulsion delivery systems and nanoemulsion excipient systems. Expert Opin. Drug Deliv. 2016, 13, 1327-1336. [CrossRef]

34. Rodríguez-Burneo, N.; Busquets, M.A.; Estelrich, J. Magnetic nanoemulsions: Comparison between nanoemulsions formed by ultrasonication and by spontaneous emulsification. Nanomaterials 2017, 7, 190. [CrossRef]

35. Hassan, A.A.; Mansour, M.K.; Sayed-ElAhl, R.M.H.; Tag El-Din, H.A.; Awad, M.E.A.; Younis, E.M. Influence of Selenium Nanoparticles on The Effects of Poisoning with Aflatoxins. Adv. Anim. Vet. Sci. 2020, 8. [CrossRef]

36. Huang, W.; Yan, M.; Duan, H.; Bi, Y.; Cheng, X.; Yu, H. Synergistic Antifungal Activity of Green Synthesized Silver Nanoparticles and Epoxiconazole against Setosphaeria turcica. J. Nanomater. 2020, 2020. [CrossRef]

37. Kischkel, B.; De Castilho, P.F.D.; De Oliveira, K.M.P.; Rezende, P.S.T.; Bruschi, M.L.; Svidzinski, T.I.E.; Negri, M.; Negri, M. Silver nanoparticles stabilized with propolis show reduced toxicity and potential activity against fungal infections. Future Microbiol. 2020, 15, 521-539. [CrossRef] [PubMed]

38. Nabawy, G.A.; Hassan, A.A.; Sayed-ElAhl, R.M.H.; Refai, M.K. Effect of Metal Nanoparticles in Comparison With Commercial Antifungal Feed Additives on the Growth of Aspergillus Flavus and Aflatoxin B1 Production. J. Glob. Biosci. 2014, 3, $954-971$.

39. Manuja, A.; Kumar, B.; Singh, R.K. Nanotechnology developments: Opportunities for animal health and production. Nanotechnol. Dev. 2012, 2, 4. [CrossRef]

40. Meena, N.S.; Sahni, Y.P.; Singh, R.P. Applications of nanotechnology in veterinary therapeutics. J. Entomol. Zool. Stud. 2018, 6, 167-175.

41. Dahman, Y. Nanoshells. In Nanotechnology and Functional Materials for Engineers; Elsevier: Amsterdam, The Netherlands, 2017; pp. 175-190; ISBN 9780323512565.

42. Loo, C.; Lin, A.; Hirsch, L.; Lee, M.H.; Barton, J.; Halas, N.; West, J.; Drezek, R. Nanoshell-Enabled Photonics-Based Imaging and Therapy of Cancer. Technol. Cancer Res. Treat. 2004, 3, 33-40. [CrossRef]

43. Loo, C.; Lin, A.; Hirsch, L.; Lee, M.H.; Barton, J.; Halas, N.; West, J.; Drezek, R. Diagnostic and Therapeutic Applications of Metal Nanoshells. Nanofabrication Towar. Biomed. Appl. Tech. Tools Appl. Impact 2005, 327-342. [CrossRef]

44. Nghiem, T.H.L.; Le, T.N.; Do, T.H.; Vu, T.T.D.; Do, Q.H.; Tran, H.N. Preparation and characterization of silica-gold core-shell nanoparticles. J. Nanoparticle Res. 2013, 15. [CrossRef]

45. Mochizuki, C.; Nakamura, J.; Nakamura, M. Development of non-porous silica nanoparticles towards cancer photo-theranostics. Biomedicines 2021, 9, 73. [CrossRef] [PubMed]

46. Dobrovolskaia, M.A.; Shurin, M.; Shvedova, A.A. Current understanding of interactions between nanoparticles and the immune system. Toxicol. Appl. Pharmacol. 2016, 299, 78-89. [CrossRef] [PubMed]

47. Chowdhury, A.; Kunjiappan, S.; Panneerselvam, T.; Somasundaram, B.; Bhattacharjee, C. Nanotechnology and nanocarrier-based approaches on treatment of degenerative diseases. Int. Nano Lett. 2017, 7, 91-122. [CrossRef]

48. Reilly, R.M. Carbon nanotubes: Potential benefits and risks of nanotechnology in nuclear medicine. J. Nucl. Med. 2007, 48, 1039-1042. [CrossRef] [PubMed]

49. Rapoport, N.; Gao, Z.; Kennedy, A. Multifunctional nanoparticles for combining ultrasonic tumor imaging and targeted chemotherapy. J. Natl. Cancer Inst. 2007, 99, 1095-1106. [CrossRef] [PubMed]

50. Bhandari, P.; Novikova, G.; Goergen, C.J.; Irudayaraj, J. Ultrasound beam steering of oxygen nanobubbles for enhanced bladder cancer therapy. Sci. Rep. 2018, 8, 1-10. [CrossRef] [PubMed]

51. Song, L.; Wang, G.; Hou, X.; Kala, S.; Qiu, Z.; Wong, K.F.; Cao, F.; Sun, L. Biogenic nanobubbles for effective oxygen delivery and enhanced photodynamic therapy of cancer. Acta Biomater. 2020, 108, 313-325. [CrossRef]

52. Shen, S.; Li, Y.; Xiao, Y.; Zhao, Z.; Zhang, C.; Wang, J.; Li, H.; Liu, F.; He, N.; Yuan, Y.; et al. Folate-conjugated nanobubbles selectively target and kill cancer cells via ultrasound-triggered intracellular explosion. Biomaterials 2018, 181, 293-306. [CrossRef]

53. Khan, M.S.; Hwang, J.; Lee, K.; Choi, Y.; Seo, Y.; Jeon, H.; Hong, J.W.; Choi, J. Anti-tumor drug-loaded oxygen nanobubbles for the degradation of HIF- $1 \alpha$ and the upregulation of reactive oxygen species in tumor cells. Cancers 2019, 11, 1464. [CrossRef]

54. Underwood, C.; van Eps, A.W. Nanomedicine and veterinary science: The reality and the practicality. Vet. J. 2012, 193, 12-23. [CrossRef]

55. Moyer, T.J.; Zmolek, A.C.; Irvine, D.J. Beyond antigens and adjuvants: Formulating future vaccines. J. Clin. Invest. 2016, 126, 799-808. [CrossRef] [PubMed]

56. Qasim Nasar, M.; Zohra, T.; Khalil, A.T.; Saqib, S.; Ayaz, M.; Ahmad, A.; Shinwari, Z.K. Seripheidium quettense mediated green synthesis of biogenic silver nanoparticles and their theranostic applications. Green Chem. Lett. Rev. 2019, 12, 310-322. [CrossRef]

57. Hassan, A.A.; Howayda, M.E.; Mahmoud, H.H. Effect of Zinc Oxide Nanoparticles on the Growth of Mycotoxigenic Mould. Stud. Chem. Process Technol. 2013, 1, 66-74.

58. Refai, H.; Badawy, M.; Hassan, A.; Sakr, H.; Baraka, Y. Antimicrobial Effect of Biologically Prepared Silver Nanoparticles (AgNPs) on Two Different Obturator's Soft Linings in Maxillectomy Patients. Eur. J. Acad. Essays 2017, 4, $15-25$.

59. Hassan, A.A.; Mansour, M.K.; Mahmoud, H. Biosynthesis of silver nanoparticles (Ag-Nps) (a model of metals) by Candida albicans and its antifungal activity on Some fungal pathogens (Trichophyton mentagrophytes and Candida albicans). N. Y. Sci. J. 2013, 6, 27-34.

60. Al Abboud, M.A. Fungal biosynthesis of silver nanoparticles and their role in control of Fusarium wilt of sweet pepper and soil-borne fungi in vitro. Int. J. Pharmacol. 2018, 14, 773-780. [CrossRef] 
61. Pietrzak, K.; Twaruzek, M.; Czyzowska, A.; Kosicki, R.; Gutarowska, B. Influence of silver nanoparticles on metabolism and toxicity of moulds. Acta Biochim. Pol. 2015, 62, 851-857. [CrossRef]

62. Abd-Elsalam, K.A.; Hashim, A.F.; Alghuthaymi, M.A.; Said-Galiev, E. Nanobiotechnological strategies for toxigenic fungi and mycotoxin control. In Food Preservation; Elsevier: Amsterdam, The Netherlands, 2017; pp. 337-364; ISBN 9780128043035.

63. Hosseini, S.S.; Mohammadi, R.; Joshaghani, H.R.; Eskandari, M. Antifungal effect of Sodium Dodecil Sulfate and Nano particle $\mathrm{ZnO}$ on growth inhibition of standard strain of Candida albicans. J. Gorgan Univ. Med. Sci. 2011, 12, 64-69.

64. Hernández-Meléndez, D.; Salas-Téllez, E.; Zavala-Franco, A.; Téllez, G.; Méndez-Albores, A.; Vázquez-Durán, A. Inhibitory effect of flower-shaped zinc oxide nanostructures on the growth and aflatoxin production of a highly toxigenic strain of Aspergillus flavus Link. Materials 2018, 11, 1265. [CrossRef]

65. Mouhamed, A.E.; Hassan, A.A.; Hassan, A.; Hariri, M.E.; Refai, M. Effect of Metal Nanoparticles on the Growth of Ochratoxigenic Moulds and Ochratoxin A Production Isolated From Food and Feed. Int. J. Res. Stud. Biosci. 2015, 3, 1-14.

66. El-Tawab, A.A.A.; El-Hofy, F.I.; Metwally, A. A Comparative Study on Antifungal Activity of $\mathrm{Fe}_{2} \mathrm{O}_{3}$, and $\mathrm{Fe}_{3} \mathrm{O}_{4} \mathrm{Nanoparticles}$ Int. J. Adv. Res. 2018, 6, 189-194. [CrossRef]

67. Kheiri, A.; Moosawi Jorf, S.A.; Mallihipour, A.; Saremi, H.; Nikkhah, M. Application of chitosan and chitosan nanoparticles for the control of Fusarium head blight of wheat (Fusarium graminearum) in vitro and greenhouse. Int. J. Biol. Macromol. 2016, 93, 1261-1272. [CrossRef]

68. Ahmed, F.; Soliman, F.M.; Adly, M.A.; Soliman, H.A.M.; El-Matbouli, M.; Saleh, M. In vitro assessment of the antimicrobial efficacy of chitosan nanoparticles against major fish pathogens and their cytotoxicity to fish cell lines. J. Fish Dis. 2020, 43, 1049-1063. [CrossRef]

69. Abd-Elsalam, K.A.; Alghuthaymi, M.A.; Shami, A.; Rubina, M.S.; Abramchuk, S.S.; Shtykova, E.V.; Vasil'kov, A.Y. Copper-chitosan nanocomposite hydrogels against aflatoxigenic Aspergillus flavus from dairy cattle feed. J. Fungi 2020, 6, 112. [CrossRef]

70. Anaraki, M.R.; Jangjoo, A.; Alimoradi, F.; Dizaj, S.M. Comparison of Antifungal Properties of Acrylic Resin Reinforced with ZnO and Ag Nanoparticles. Tabriz Univ. Med. Sci. 2017, 23, 207-214. [CrossRef]

71. Shokrollahi, H. Structure, synthetic methods, magnetic properties and biomedical applications of ferrofluids. Mater. Sci. Eng. C 2013, 33, 2476-2487. [CrossRef] [PubMed]

72. Atef, H.A.; Mansour, M.K.; Ibrahim, E.M.; Sayed-ElAhl, R.M.H.; Al-Kalamawey, N.M.; El Kattan, Y.A.; Ali, M.A. Efficacy of Zinc Oxide Nanoparticles and Curcumin in Amelioration the Toxic Effects in Aflatoxicated Rabbits. Int. J. Curr. Microbiol. Appl. Sci. 2016, 5, 795-818. [CrossRef]

73. Sanchez, V.C.; Jachak, A.; Hurt, R.H.; Kane, A.B. Biological Interactions of Graphene-Family Nanomaterials: An Interdisciplinary Review. Chem. Res. Toxicol. 2012, 25, 15-34. [CrossRef] [PubMed]

74. Hassan, A.A.; Oraby, N.H.; Manal, M.E.-M. Detection of Mycotoxigenic Fusarium Species in Poultry Rations and Their Detection of Mycotoxigenic Fusarium Species in Poultry Rations and Their Growth Control by Zinc Nanoparticles. Anim. Health Res. J. 2019, 7, 1075-1091.

75. Wang, J.J.; Liu, B.H.; Hsu, Y.T.; Yu, F.Y. Sensitive competitive direct enzyme-linked immunosorbent assay and gold nanoparticle immunochromatographic strip for detecting aflatoxin M1 in milk. Food Control 2011, 22, 964-969. [CrossRef]

76. Osama, E.; El-Sheikh, S.M.A.; Khairy, M.H.; Galal, A.A.A. Nanoparticles and their potential applications in veterinary medicine. J. Adv. Vet. Res. 2020, 10, 268-273.

77. Hamad, K.M.; Mahmoud, N.N.; Al-Dabash, S.; Al-Samad, L.A.; Abdallah, M.; Al-Bakri, A.G. Fluconazole conjugated-gold nanorods as an antifungal nanomedicine with low cytotoxicity against human dermal fibroblasts. RSC Adv. 2020, 10, 25889-25897. [CrossRef]

78. Carvalho, G.C.; Sábio, R.M.; de Cássia Ribeiro, T.; Monteiro, A.S.; Pereira, D.V.; Ribeiro, S.J.L.; Chorilli, M. Highlights in Mesoporous Silica Nanoparticles as a Multifunctional Controlled Drug Delivery Nanoplatform for Infectious Diseases Treatment. Pharm. Res. 2020, 37. [CrossRef]

79. Vallet-Regí, M. Mesoporous Silica Nanoparticles: Their Projection in Nanomedicine. ISRN Mater. Sci. 2012, 2012, 1-20. [CrossRef]

80. Castillo, R.R.; Lozano, D.; Vallet-Regí, M. Mesoporous silica nanoparticles as carriers for therapeutic biomolecules. Pharmaceutics 2020, 12, 432. [CrossRef]

81. Kanugala, S.; Jinka, S.; Puvvada, N.; Banerjee, R.; Kumar, C.G. Phenazine-1-carboxamide functionalized mesoporous silica nanoparticles as antimicrobial coatings on silicone urethral catheters. Sci. Rep. 2019, 9, 1-16. [CrossRef] [PubMed]

82. Montazeri, M.; Razzaghi-Abyaneh, M.; Nasrollahi, S.A.; Maibach, H.; Nafisi, S. Enhanced topical econazole antifungal efficacy by amine-functionalized silica nanoparticles. Bull. Mater. Sci. 2020, 43. [CrossRef]

83. Deaguero, I.G.; Huda, M.N.; Rodriguez, V.; Zicari, J.; Al-hilal, T.A.; Badruddoza, A.Z.M.; Nurunnabi, M. Nano-vesicle based anti-fungal formulation shows higher stability, skin diffusion, biosafety and anti-fungal efficacy in vitro. Pharmaceutics 2020, 12, 516. [CrossRef]

84. Siopi, M.; Mouton, J.W.; Pournaras, S.; Meletiadis, J. In Vitro and In Vivo Exposure-Effect Relationship of Liposomal Amphotericin B against Aspergillus fumigatus. Antimicrob. Agents Chemother. 2019, 63, 1-7. [CrossRef]

85. Kunjumon, S.; Krishnakumar, K.; Nair, S.K. Nanomicelles Formulation: In Vitro Anti-Fungal Study. Int. J. Pharm. Sci. Rev. Res. 2020, 62, 78-81.

86. Lee, A.L.Z.; Wang, Y.; Pervaiz, S.; Fan, W.; Yang, Y.Y. Synergistic Anticancer Effects Achieved by Co-Delivery of TRAIL and Paclitaxel Using Cationic Polymeric Micelles. Macromol. Biosci. 2011, 11, 296-307. [CrossRef] 
87. Vail, D.M.; von Euler, H.; Rusk, A.W.; Barber, L.; Clifford, C.; Elmslie, R.; Fulton, L.; Hirschberger, J.; Klein, M.; London, C.; et al. A Randomized Trial Investigating the Efficacy and Safety of Water Soluble Micellar Paclitaxel (Paccal Vet) for Treatment of Nonresectable Grade 2 or 3 Mast Cell Tumors in Dogs. J. Vet. Intern. Med. 2012, 26, 598-607. [CrossRef]

88. Malachowski, T.; Hassel, A. Engineering nanoparticles to overcome immunological barriers for enhanced drug delivery. Eng. Regen. 2020, 1, 35-50. [CrossRef]

89. Kurantowicz, N.; Strojny, B.; Sawosz, E.; Jaworski, S.; Kutwin, M.; Grodzik, M.; Wierzbicki, M.; Lipińska, L.; Mitura, K.; Chwalibog, A. Biodistribution of a High Dose of Diamond, Graphite, and Graphene Oxide Nanoparticles After Multiple Intraperitoneal Injections in Rats. Nanoscale Res. Lett. 2015, 10. [CrossRef]

90. Ajmal, M.; Yunus, U.; Matin, A.; Haq, N.U. Synthesis, characterization and in vitro evaluation of methotrexate conjugated fluorescent carbon nanoparticles as drug delivery system for human lung cancer targeting. J. Photochem. Photobiol. B Biol. 2015, 153, 111-120. [CrossRef] [PubMed]

91. Kim, J.M.; Kim, D.H.; Park, H.J.; Ma, H.W.; Park, I.S.; Son, M.; Ro, S.Y.; Hong, S.; Han, H.K.; Lim, S.J.; et al. Nanocomposites-based targeted oral drug delivery systems with infliximab in a murine colitis model. J. Nanobiotechnology 2020, 18, 1-13. [CrossRef] [PubMed]

92. Paskiabi, F.A.; Bonakdar, S.; Shokrgozar, M.A.; Imani, M.; Jahanshiri, Z.; Shams-Ghahfarokhi, M.; Razzaghi-Abyaneh, M. Terbinafine-loaded wound dressing for chronic superficial fungal infections. Mater. Sci. Eng. C 2017, 73, 130-136. [CrossRef] [PubMed]

93. El-Nahass, E.-S.; Moselhy, W.A.; Hassan, N.E.-H.Y.; Hassan, A.A. Evaluation of the Protective Effects of Adsorbent Materials and Ethanolic Herbal Extracts against Aflatoxins Hepatotoxicity in Albino Rats: Histological, Morphometric and Immunohistochemical Study. Adv. Anim. Vet. Sci. 2019, 7, 1140-1147. [CrossRef]

94. Abd El-Fatah, S.; Bakry, H.; Abo Salem, M.; Hassan, A. Comparative Study between the Use of Bulk and Nanoparticles of Zinc Oxide in Amelioration the Toxic Effects of Aflatoxins in rats. Benha Vet. Med. J. 2017, 33, 329-342. [CrossRef]

95. Gholami-Ahangaran, M.; Zia-Jahromi, N. Nanosilver effects on growth parameters in experimental aflatoxicosis in broiler chickens. Toxicol. Ind. Health 2013, 29, 121-125. [CrossRef]

96. Gholami-Ahangaran, M.; Zia-Jahromi, N. Effect of nanosilver on blood parameters in chickens having aflatoxicosis. Toxicol. Ind. Health 2014, 30, 192-196. [CrossRef]

97. Asghari-Paskiabi, F.; Imani, M.; Rafii-Tabar, H.; Razzaghi-Abyaneh, M. Physicochemical properties, antifungal activity and cytotoxicity of selenium sulfide nanoparticles green synthesized by Saccharomyces cerevisiae. Biochem. Biophys. Res. Commun. 2019, 516, 1078-1084. [CrossRef]

98. Fadl, S.E.; El-Shenawy, A.M.; Gad, D.M.; El Daysty, E.M.; El-Sheshtawy, H.S.; Abdo, W.S. Trial for reduction of Ochratoxin A residues in fish feed by using nano particles of hydrated sodium aluminum silicates (NPsHSCAS) and copper oxide. Toxicon 2020, 184, 1-9. [CrossRef]

99. Gibson, N.M.; Luo, T.J.M.; Brenner, D.W.; Shenderova, O. Immobilization of mycotoxins on modified nanodiamond substrates. Biointerphases 2011, 6, 210-217. [CrossRef]

100. Asghar, M.A.; Zahir, E.; Shahid, S.M.; Khan, M.N.; Asghar, M.A.; Iqbal, J.; Walker, G. Iron, copper and silver nanoparticles: Green synthesis using green and black tea leaves extracts and evaluation of antibacterial, antifungal and aflatoxin B1 adsorption activity. LWT Food Sci. Technol. 2018, 90, 98-107. [CrossRef]

101. Moghaddam, S.H.M.; Jebali, A.; Daliri, K. The Use of Mgo-Sio2 Nanocomposite for Adsorption of Aflatoxin in Wheat Flour Samples. In Proceedings of the NanoCon 2010, Olomouc, Czech Republic, 12-14 October 2010; pp. $10-15$.

102. Scorzoni, L.; de Paula e Silva, A.C.A.; Marcos, C.M.; Assato, P.A.; de Melo, W.C.M.A.; de Oliveira, H.C.; Costa-Orlandi, C.B.; Mendes-Giannini, M.J.S.; Fusco-Almeida, A.M. Antifungal therapy: New advances in the understanding and treatment of mycosis. Front. Microbiol. 2017, 8, 1-23. [CrossRef] [PubMed]

103. Arias, L.S.; Pessan, J.P.; de Souza Neto, F.N.; Lima, B.H.R.; de Camargo, E.R.; Ramage, G.; Delbem, A.C.B.; Monteiro, D.R. Novel nanocarrier of miconazole based on chitosan-coated iron oxide nanoparticles as a nanotherapy to fight Candida biofilms. Colloids Surf. B Biointerfaces 2020, 192, 111080. [CrossRef]

104. Araujo, H.C.; da Silva, A.C.G.; Paião, L.I.; Magario, M.K.W.; Frasnelli, S.C.T.; Oliveira, S.H.P.; Pessan, J.P.; Monteiro, D.R. Antimicrobial, antibiofilm and cytotoxic effects of a colloidal nanocarrier composed by chitosan-coated iron oxide nanoparticles loaded with chlorhexidine. J. Dent. 2020, 101. [CrossRef] [PubMed]

105. Zahoor, M.; Ali Khan, F. Adsorption of aflatoxin B1 on magnetic carbon nanocomposites prepared from bagasse. Arab. J. Chem. 2018, 11, 729-738. [CrossRef]

106. Pirouz, A.A.; Selamat, J.; Iqbal, S.Z.; Mirhosseini, H.; Karjiban, R.A.; Bakar, F.A. The use of innovative and efficient nanocomposite (magnetic graphene oxide) for the reduction on of Fusarium mycotoxins in palm kernel cake. Sci. Rep. 2017, 7, 1-9. [CrossRef] [PubMed]

107. Gao, R.; Meng, Q.; Li, J.; Liu, M.; Zhang, Y.; Bi, C.; Shan, A. Modified halloysite nanotubes reduce the toxic effects of zearalenone in gestating sows on growth and muscle development of their offsprings. J. Anim. Sci. Biotechnol. 2016, 7, 1-9. [CrossRef]

108. Ji, J.; Xie, W. Detoxification of Aflatoxin B1 by magnetic graphene composite adsorbents from contaminated oils. J. Hazard. Mater. 2020, 381, 120915. [CrossRef] 
109. González-Jartín, J.M.; de Castro Alves, L.; Alfonso, A.; Piñeiro, Y.; Vilar, S.Y.; Gomez, M.G.; Osorio, Z.V.; Sainz, M.J.; Vieytes, M.R.; Rivas, J.; et al. Detoxification agents based on magnetic nanostructured particles as a novel strategy for mycotoxin mitigation in food. Food Chem. 2019, 294, 60-66. [CrossRef]

110. Zhai, X.; Zhang, C.; Zhao, G.; Stoll, S.; Ren, F.; Leng, X. Antioxidant capacities of the selenium nanoparticles stabilized by chitosan. J. Nanobiotechnology 2017, 15, 1-12. [CrossRef]

111. Luo, Y.; Zhou, Z.; Yue, T. Synthesis and characterization of nontoxic chitosan-coated $\mathrm{Fe}_{3} \mathrm{O}_{4}$ particles for patulin adsorption in a juice-pH simulation aqueous. Food Chem. 2017, 221, 317-323. [CrossRef]

112. Hamza, Z.; El-Hashash, M.; Aly, S.; Hathout, A.; Soto, E.; Sabry, B.; Ostroff, G. Preparation and characterization of yeast cell wall beta-glucan encapsulated humic acid nanoparticles as an enhanced aflatoxin B1 binder. Carbohydr. Polym. 2019, 203, 185-192 [CrossRef]

113. Nikolova, M.P.; Chavali, M.S. Metal oxide nanoparticles as biomedical materials. Biomimetics 2020, 5, 27. [CrossRef]

114. Norouzi, M.; Yathindranath, V.; Thliveris, J.A.; Kopec, B.M.; Siahaan, T.J.; Miller, D.W. Doxorubicin-loaded iron oxide nanoparticles for glioblastoma therapy: A combinational approach for enhanced delivery of nanoparticles. Sci. Rep. 2020, 10, 1-18. [CrossRef] [PubMed]

115. Soetaert, F.; Korangath, P.; Serantes, D.; Fiering, S.; Ivkov, R. Cancer therapy with iron oxide nanoparticles: Agents of thermal and immune therapies. Adv. Drug Deliv. Rev. 2020, 163-164, 65-83. [CrossRef] [PubMed]

116. Nabil, A.; Elshemy, M.M.; Asem, M.; Abdel-Motaal, M.; Gomaa, H.F.; Zahran, F.; Uto, K.; Ebara, M. Zinc Oxide Nanoparticle Synergizes Sorafenib Anticancer Efficacy with Minimizing Its Cytotoxicity. Oxid. Med. Cell. Longev. 2020, 2020. [CrossRef] [PubMed]

117. Xu, C.; Sun, S. New forms of superparamagnetic nanoparticles for biomedical applications. Adv. Drug Deliv. Rev. 2013, 65, 732-743. [CrossRef]

118. Smith, T.; Affram, K.; Nottingham, E.L.; Han, B.; Amissah, F.; Krishnan, S.; Trevino, J.; Agyare, E. Application of smart solid lipid nanoparticles to enhance the efficacy of 5-fluorouracil in the treatment of colorectal cancer. Sci. Rep. 2020, 10, 1-14. [CrossRef]

119. Xie, P.; Yang, S.T.; He, T.; Yang, S.; Tang, X.H. Bioaccumulation and toxicity of carbon nanoparticles suspension injection in intravenously exposed mice. Int. J. Mol. Sci. 2017, 18, 2562. [CrossRef]

120. Frank, A.; Eric, M.P.; Robert, L.; Omid, C.F. Nanoparticles Technologies For Cancer Therapy. In Drug Delievery; Springer: Berlin/Heidelberg, Germany, 2010; Volume 197, ISBN 978-3-642-00476-6.

121. Axiak-Bechtel, S.M.; Upendran, A.; Lattimer, J.C.; Kelsey, J.; Cutler, C.S.; Selting, K.A.; Bryan, J.N.; Henry, C.J.; Boote, E.; Tate, D.J.; et al. Gum arabic-coated radioactive gold nanoparticles cause no short-term local or systemic toxicity in the clinically relevant canine model of prostate cancer. Int. J. Nanomedicine 2014, 9, 5001-5011. [CrossRef] [PubMed]

122. Lu, J.; Liong, M.; Li, Z.; Zink, J.I.; Tamanoi, F. Biocompatibility, Biodistribution, and Drug-Delivery Efficiency of Mesoporous Silica Nanoparticles for Cancer Therapy in Animals. Small 2010, 6, 1794-1805. [CrossRef] [PubMed]

123. Xiao, Y.D.; Paudel, R.; Liu, J.; Ma, C.; Zhang, Z.S.; Zhou, S.K. MRI contrast agents: Classification and application (Review). Int. J. Mol. Med. 2016, 38, 1319-1326. [CrossRef] [PubMed]

124. Soenen, S.J.H.; Himmelreich, U.; Nuytten, N.; Pisanic, T.R.; Ferrari, A.; De Cuyper, M. Intracellular Nanoparticle Coating Stability Determines Nanoparticle Diagnostics Efficacy and Cell Functionality. Small 2010, 6. [CrossRef]

125. Thomas, G.; Boudon, J.; Maurizi, L.; Moreau, M.; Walker, P.; Severin, I.; Oudot, A.; Goze, C.; Poty, S.; Vrigneaud, J.M.; et al Innovative Magnetic Nanoparticles for PET/MRI Bimodal Imaging. ACS Omega 2019, 4, 2637-2648. [CrossRef]

126. Lee, C.; Kim, J.; Zhang, Y.; Jeon, M.; Liu, C.; Song, L.; Lovell, J.F.; Kim, C. Dual-color photoacoustic lymph node imaging using nanoformulated naphthalocyanines. Biomaterials 2015, 73, 142-148. [CrossRef]

127. Martynenko, I.V.; Litvin, A.P.; Purcell-Milton, F.; Baranov, A.V.; Fedorov, A.V.; Gun'Ko, Y.K. Application of semiconductor quantum dots in bioimaging and biosensing. J. Mater. Chem. B 2017, 5, 6701-6727. [CrossRef]

128. Feugang, J.M.; Youngblood, R.C.; Greene, J.M.; Willard, S.T.; Ryan, P.L. Self-illuminating quantum dots for non-invasive bioluminescence imaging of mammalian gametes. J. Nanobiotechnology 2015, 13, 1-16. [CrossRef]

129. Chen, F.; Gerion, D. Fluorescent CdSe/ZnS nanocrystal-peptide conjugates for long-term, nontoxic imaging and nuclear targeting in living cells. Nano Lett. 2004, 4, 1827-1832. [CrossRef]

130. Wagner, A.M.; Knipe, J.M.; Orive, G.; Peppas, N.A. Quantum dots in biomedical applications. Acta Biomater. 2019, 94, 44-63. [CrossRef]

131. Dey, R.; Mazumder, S.; Mitra, M.K.; Mukherjee, S.; Das, G.C. Review: Biofunctionalized quantum dots in biology and medicine. J. Nanomater. 2009, 2009. [CrossRef]

132. Matea, C.T.; Mocan, T.; Tabaran, F.; Pop, T.; Mosteanu, O.; Puia, C.; Iancu, C.; Mocan, L. Quantum dots in imaging, drug delivery and sensor applications. Int. J. Nanomedicine 2017, 12, 5421-5431. [CrossRef]

133. Abdel-Salam, M.; Omran, B.; Whitehead, K.; Baek, K.H. Superior properties and biomedical applications of microorganismderived fluorescent quantum dots. Molecules 2020, 25, 4486. [CrossRef] [PubMed]

134. Sahoo, S.L.; Liu, C.H.; Kumari, M.; Wu, W.C.; Wang, C.C. Biocompatible quantum dot-antibody conjugate for cell imaging, targeting and fluorometric immunoassay: Crosslinking, characterization and applications. RSC Adv. 2019, 9, 32791-32803. [CrossRef]

135. Patric Joshua, P.; Valli, C.; Balakrishnan, V. Effect of in ovo supplementation of nano forms of zinc, copper, and selenium on post-hatch performance of broiler chicken. Vet. World 2016, 9, 287-294. [CrossRef] 
136. Scott, A.; Vadalasetty, K.P.; Chwalibog, A.; Sawosz, E. Copper nanoparticles as an alternative feed additive in poultry diet: A review. Nanotechnol. Rev. 2018, 7, 69-93. [CrossRef]

137. Mishra, A.; Swain, R.; Mishra, S.; Panda, N.; Sethy, K. Growth performance and serum biochemical parameters as affected by nano zinc supplementation in layer chicks. Indian J. Anim. Nutr. 2014, 31, 384-388.

138. Swain, P.S.; Rajendran, D.; Rao, S.B.N.; Dominic, G. Preparation and effects of nano mineral particle feeding in livestock: A review. Vet. World 2015, 8, 888-891. [CrossRef]

139. Bhanja, S.K.; Hotowy, A.; Mehra, M.; Sawosz, E.; Pineda, L.; Vadalasetty, K.P.; Kurantowicz, N.; Chwalibog, A. In ovo administration of silver nanoparticles and/or amino acids influence metabolism and immune gene expression in chicken embryos. Int. J. Mol. Sci. 2015, 16, 9484-9503. [CrossRef] [PubMed]

140. Feugang, J.M.; Youngblood, R.C.; Greene, J.M.; Fahad, A.S.; Monroe, W.A.; Willard, S.T.; Ryan, P.L. Application of quantum dot nanoparticles for potential non-invasive bio-imaging of mammalian spermatozoa. J. Nanobiotechnology 2012, 10, 1-8. [CrossRef] [PubMed]

141. Petruska, P.; Capcarova, M.; Sutovsky, P. Antioxidant supplementation and purification of semen for improved artificial insemination in livestock species. Turkish J. Vet. Anim. Sci. 2014, 38, 643-652. [CrossRef]

142. Barkalina, N.; Jones, C.; Kashir, J.; Coote, S.; Huang, X.; Morrison, R.; Townley, H.; Coward, K. Effects of mesoporous silica nanoparticles upon the function of mammalian sperm in vitro. Nanomedicine Nanotechnology Biol. Med. 2014, 10, 859-870. [CrossRef] [PubMed]

143. Pawar, K.; Kaul, G. Toxicity of titanium oxide nanoparticles causes functionality and DNA damage in buffalo (Bubalus bubalis) sperm in vitro. Toxicol. Ind. Health 2014, 30, 520-533. [CrossRef] [PubMed]

144. Rey, A.I.; Segura, J.; Arandilla, E.; López-Bote, C.J. Short- and long-term effect of oral administration of micellized natural vitamin $\mathrm{E}$ (D- $\alpha$-tocopherol) on oxidative status in race horses under intense training. J. Anim. Sci. 2013, 91, 1277-1284. [CrossRef]

145. Rey, A.; Amazan, D.; Cordero, G.; Olivares, A.; López-Bote, C.J. Lower Oral Doses of Micellized $\alpha$-Tocopherol Compared to $\alpha$-Tocopheryl Acetate in Feed Modify Fatty Acid Profiles and Improve Oxidative Status in Pigs. Int. J. Vitam. Nutr. Res. 2014, 84, 229-243. [CrossRef] [PubMed]

146. King, T.; Osmond-McLeod, M.J.; Duffy, L.L. Nanotechnology in the food sector and potential applications for the poultry industry. Trends Food Sci. Technol. 2018, 72, 62-73. [CrossRef]

147. Stankic, S.; Suman, S.; Haque, F.; Vidic, J. Pure and multi metal oxide nanoparticles: Synthesis, antibacterial and cytotoxic properties. J. Nanobiotechnology 2016, 14, 1-20. [CrossRef]

148. Hwang, I.S.; Lee, J.; Hwang, J.H.; Kim, K.J.; Lee, D.G. Silver nanoparticles induce apoptotic cell death in Candida albicans through the increase of hydroxyl radicals. FEBS J. 2012, 279, 1327-1338. [CrossRef] [PubMed]

149. Kalia, A.; Abd-Elsalam, K.A.; Kuca, K. Zinc-based nanomaterials for diagnosis and management of plant diseases: Ecological safety and future prospects. J. Fungi 2020, 6, 222. [CrossRef] [PubMed]

150. Dilbaghi, N.; Kaur, H.; Kumar, R.; Arora, P.; Kumar, S. Nanoscale device for veterinay technology: Trends and future prospective. Adv. Mater. Lett. 2013, 4, 175-184. [CrossRef]

151. Oberdörster, G.; Kuhlbusch, T.A.J. In vivo effects: Methodologies and biokinetics of inhaled nanomaterials. NanoImpact 2018, 10, 38-60. [CrossRef]

152. Aschberger, K.; Micheletti, C.; Sokull-Klüttgen, B.; Christensen, F.M. Analysis of currently available data for characterising the risk of engineered nanomaterials to the environment and human health-Lessons learned from four case studies. Environ. Int. 2011, 37, 1143-1156. [CrossRef]

153. Barkhordari, A.; Hekmatimoghaddam, S.; Jebali, A.; Khalili, M.A.; Talebi, A.; Noorani, M. Effect of zinc oxide nanoparticles on viability of human spermatozoa. Int. J. Reprod. Biomed. 2013, 11,767-771.

154. Baltic, M.; Boskovic, M.; Ivanovic, J.; Dokmanovic, M.; Janjic, J.; Loncina, J.; Baltic, T. Nanotechnology and its potential applications in meat industry. Tehnologija Mesa 2013, 54, 168-175. [CrossRef]

155. Elder, A.; Lynch, I.; Grieger, K.; Chan-Remillard, S.; Gatti, A.; Gnewuch, H.; Kenawy, E.; Korenstein, R.; Kuhlbusch, T.; Linker, F.; et al. Human Health Risks of Engineered Nanomaterials. In Nanomaterials: Risks and Benefits; Linkov, I., Steevens, J., Eds.; Springer Science+Business Media: New York, NY, USA, 2009; pp. 3-29.

156. Pekkanen, J.; Peters, A.; Hoek, G.; Tiittanen, P.; Brunekreef, B.; De Hartog, J.; Heinrich, J.; Ibald-Mulli, A.; Kreyling, W.G.; Lanki, T.; et al. Particulate air pollution and risk of ST-segment depression during repeated submaximal exercise tests among subjects with coronary heart disease: The exposure and risk assessment for fine and ultrafine particles in ambient air (ULTRA) study. Circulation 2002, 106, 933-938. [CrossRef]

157. Nurkiewicz, T.R.; Porter, D.W.; Hubbs, A.F.; Cumpston, J.L.; Chen, B.T.; Frazer, D.G.; Castranova, V. Nanoparticle inhalation augments particle-dependent systemic microvascular dysfunction. Part. Fibre Toxicol. 2008, 5, 1-12. [CrossRef]

158. Oberdörster, G.; Castranova, V.; Asgharian, B.; Sayre, P. Inhalation exposure to carbon nanotubes (CNT) and carbon nanofibers (CNF): Methodology and Dosimetry. J. Toxicol. Environ. Health Part B Crit. Rev. 2015, 18, 121-212. [CrossRef]

159. Orsi, M.; Al Hatem, C.; Leinardi, R.; Huaux, F. Carbon nanotubes under scrutiny: Their toxicity and utility in mesothelioma research. Appl. Sci. 2020, 10, 4513. [CrossRef]

160. Chopra, M.; Bernela, M.; Kaur, P.; Manuja, A.; Kumar, B.; Thakur, R. Alginate/gum acacia bipolymeric nanohydrogels-Promising carrier for Zinc oxide nanoparticles. Int. J. Biol. Macromol. 2015, 72, 827-833. [CrossRef] [PubMed] 